\title{
Development or Despair? The Intentions and Realities of South-South Migration
}

\author{
Sang E. Lee \\ University of California Berkeley. College of Natural Resources. 137 Mulford Hall, Berkeley, CA 94720 \\ United States. Phone: (510) 642-2332, Email: sangelee@berkeley.edu
}

\section{Received: September, 2010 / Accepted: October, 2010}

\section{6}

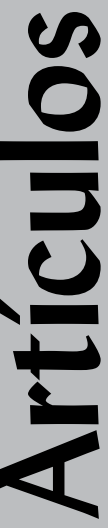

THE LITERATURE ON THE MOTIVATIONS AND THE IMPACTS OF REMITTANCES sent by international migrants to their families and communities strongly focus on their economic impacts and the flows of money from the global North to the South. The driving factors for remittance sending, closely embedded in motivations for migration, often overlook the conditions in which remittances are not sent, where households do not prosper, and community development does not happen. This ethnographic study uses the case of Nicaraguan migration to Costa Rica to examine the lives of the families of migrants in the context of rural to rural and South to South migration. The paper examines the intentions and realities of South-South migration through the lens of migrants and their families, and illuminates the other side of migration often invisible in the migrant's home communities and the migration and development literature. The paper also shows the disparity in physical, economic, and emotional distance as it illustrates the unique structural challenges of South-South and especially rural to rural migrants. These structural barriers that create an unbridgeable distance between migrants and their families embody the chasm between the intentions and the realities of migration for individuals on both sides of the border.

Key words: Remittance / Migration / Rural / South-South Migration / Costa Rica / Nicaragua

\section{¿Desarollo o desesparacíon? Los intentos y las realidades de la migración entre dos países en el Sur}

La literatura sobre las motivaciones y los impactos de las remesas enviadas por migrantes internacionales a sus familias y comunidades se centra fuertemente sobre sus impactos económicos y los flujos de dinero desde el Norte al Sur. Los principales factores de envío de remesas, imbricados en las motivaciones de la migración, a menudo pasan por alto las condiciones en que las remesas no son enviadas, donde los hogares no prosperan, y el desarrollo comunitario no sucede. Este estudio etnográfico utiliza el caso de la migración de nicaragüenses a Costa Rica para examinar las vidas de las familias de los migrantes en el contexto rural 
y de migración entre los países en el Sur. El artículo examina las intenciones y las realidades de la migración Sur-Sur a través del lente de los migrantes y sus familias, y se ilumina el otro lado de la migración, a menudo invisible en la comunidad de origen del migrante y la literatura sobre migración y desarrollo. Este trabajo muestra la disparidad en la distancia física, emocional y económica, ya que ilustra los desafíos estructurales únicos los migrantes Sur-Sur y de contexto rural. Estas barreras estructurales que crean una distancia insalvable entre los migrantes y sus familias, encarnan la diferencia abismal entre las intenciones y las realidades de la migración de personas a ambos lados de la frontera.

Palabras clave: remesa / migración / rural / migración sur-sur / Costa Rica / Nicaragua

He [her son] left two years ago and left me his two sons [two boys, age five and three] and has not come back. He sent money in the beginning and now we have not heard from him in seven months! It is not enough for him to send money every three months like he did, because we get hungry every day (Adela ${ }^{1}$, Mar. 7, 2006).

\section{Introduction}

I sat on a sack of corn in Adela's small house made of mud bricks. There was no furniture. She was cooking beans in a clay pot over a small fire in the corner of the main living space. I had conducted the initial interview with her early in the morning, and then she had sent one of her grandchildren to find me in town because she had more to say. She started out by explaining that during my initial visit, she was nervous and that was why she was quiet. Since then, she thought about my questions and wanted to answer them thoroughly and tell me more about her situation and her analysis of the situation of Nicaraguan migrants in Costa Rica in general. She explained that Nicaraguans in Costa Rica used to make money, but now they do not. Her son, for example, has not sent any money since he migrated. She explained to me that migration is not for everyone; not everyone can go and become the successful migrant abroad. As she lamented about her situation and the situation of many of the families of migrants in Nicaragua, the structural challenges associated with connecting from one rural locality to another slowly unraveled. She stated that her son could call a cellular phone in the next village over where there is cell phone reception, they could deliver a message to her stating the time and date that he was going to call, then she could make the two hour walk to wait for his phone call. The scenario she describes is an ideal one and does not take into account whether there will be cell service that day, the batteries would be charged on the phone, her son in Costa Rica would be able to get to a pay phone, and that the lines would be free enough to make the connection. The scenario that Adela describes reflects the disparity between the relative short geographic distance and the structural distance between two rural localities in the global South. This paper demonstrates the significance of the structural distance between two communities that contributes to economic and emotional disconnection between Nicaraguan migrants and their families. 
The visits to families of migrants initially incited outbursts that reminded them of the fissure in their lives, exposing the everyday costs of migration that are often shadowed in the remittance and development literature, which highlights "successful" migrants and their economic contributions to their families and to the economic development of their home country. These fissures are the manifestations of the structural boundaries and limitations that exist in migration between the global South, especially between two rural localities. The experiences of migrants' families in Nicaragua and of the migrants in Costa Rica tell a different story than the one told by studies of the development potential of South-North migrant remittances and reveal the dramatic social and economic shifts in Nicaragua's countryside. The emotional costs stemming from the disparity between the intentions and the realities of South-South migration unveil how families back home at best cope with (and not necessarily flourish from) international migration. The findings show the persistent contradictions in the migrant's perceptions and their family's realities, expose the disparity between the physical and emotional distance prevalent in South-South migration, and reveal the realities of struggles facing the migrants and their families caught in a liminal state of anticipation and waiting. Illuminating the emotional and unquantifiable costs of migration, exposes the perpetuation of underdevelopment through migration in the Nicaraguan countryside at the household level.

Adela's family's migration situation is a stark contrast from what I expected to see and hear from my visits with the families of migrants. Her house did not have shiny new electrical appliances brought back from Costa Rica, nor were there plastic chairs or cement floors purchased with remittance money. Rather, what I found was Adela's despair and frustration with the responsibility to feed her grandchildren and daughter-in-law compounded with the endless waiting for remittance money. In the case of migrants moving from one country in the global South to another, how much of their remittances are contributing to economic development, both in the sense of raising the individual standards of living and through structural changes in investment and infrastructure? The remittance literature suggests that the amount is considerable (Orozco, 2002, 2003; Ratha, 2003; Ratha \& Shaw, 2007); but in the rural villages in Nicaragua, that money was nowhere to be seen. While it is much easier to see the presence of migrants in Costa Rica and how they are changing the economic and social landscape, observing absence in Nicaragua, and the subsequent changes there, was much more subtle. How are the connections between migrants and their families, or lack thereof, changing the lived experiences of the families left behind? In seeking the answers to these questions, I interviewed migrants and their families on both sides of the border: first with Nicaraguan migrants in Costa Rica, and then visiting their families in Nicaragua. I also conducted a 65-question survey ${ }^{2}$ focused on migration dynamics in nine villages in the northern and southern regions of Nicaragua, with families of migrants to get a village-level understanding of migration dynamics.

I traveled from village to village in the Department of Matagalpa in the North and Nueva Guinea region in the South, searching for the families of migrants whom I met in Costa Rica. With their family's names and vague directions, of the 110 migrants interviewed I selected 45 of their families to visit and succeeded in visiting 33 families. ${ }^{3}$ I also conducted 121 household surveys that consisted of economic and migration family histories. During nearly all of the visits (other than four visits in which the migrants had already returned 
to Nicaragua) families expressed distress, frustration, confusion, and despair. No matter how I approached it, it was impossible to evade their initial shock when I asked if they were the family of the migrant whom I met in Costa Rica. I quickly learned to immediately jump to the statement that there was nothing wrong, and that their relative was safe and alive. Many of them stated later on in the interview that they assumed I was there to tell them that their family member was either dead or imprisoned. I found this to be particularly peculiar because the migrants in Costa Rica explicitly stated that they kept in touch with their families, which is why I chose to visit them. Over half of the 110 migrants I interviewed in Costa Rica stated that they did not keep in touch with their families at all, and many of them did not even know where their families lived. Through the family visits, I made a transnational connection between the migrant and his/her family vaguely similar to if the migrant were to visit. I brought photos of the migrants in Costa Rica as proof to the families that I knew their relative and that they were in good health, and I gave them the recent photo of their relative. I carried a set of pictures of the town where they lived and the farms they worked on. I also gave every migrant the option to send a letter back home, although, only one chose to do so. I transported photos, stories, and a letter from Costa Rica to remote villages in Nicaragua and then from Nicaragua back to Costa Rica with more photos and letters in hand. I attempt to communicate some of the despair and frustration from the families while examining the foundations of their frustration.

\section{Remittances and Development for Whom?}

Explanations of remittance motivations and behavior are deeply embedded in the new economics of labor migration (NELM), which shifts the unit of decision-making in migration from the individual to the household (Stark \& Taylor, 1991). The new economics of migration theory is an alternative explanation for migration initiation. The NELM perspective challenges micro aspects of neoclassical theory by arguing that migration is not the result of the choices of individual rational actors, but rather decisions made by households or larger units acting collectively to increase and diversify income (Stark \& Bloom, 1985). Conceptualizing the family as the decision-maker for migration changes the financial capacity of the migrant: if the family as a collective gathers resources so that migration can occur, the migrant's obligation to the family is, consequently, greater than if s/he had made the decision and gathered the resources alone. NELM suggests that decisions made collectively by the family will result in an increase in the frequency and/or quantity of remittances sent by the migrant, who is assumed to feel obligated to his/her family, which supported the migration. Altruism on both sides of the border is what keeps the flow of remittances (Stark \& Lucas, 1988). On one hand, the migrants keep their place in the family and enhance the family's economic security through remittances (Stark \& Lucas, 1988). On the other hand, the family provides the security of a home for the migrant to return to when s/he is faced with an insecure labor market abroad (Stark \& Lucas, 1988). In the context of North-South migration, remittances are sent and received as a form of obligation and, ironically, self-interested altruism.

The drive for migration, and the purpose of remittances, is to mitigate the domestic market failures in the sending country, rather than in the neoclassical view, where it is said that the wages or the labor market in the destination country is what motivates individuals to migrate (Stark \& Taylor, 1991). Under the NELM framework, families in the South, or in the 
home country, use remittances to mitigate the risks that they face due to the failures in the domestic economy, which are identified as lack of credit for farm inputs, crop insurance, unemployment benefits, social security, and healthcare (Stark \& Bloom, 1985; Stark \& Lucas, 1988; Stark \& Taylor, 1991). Failures in the domestic market economy are common in the South and threaten the well-being of households. Households may decide to migrate to mitigate the risks they face as a collective rather than as individuals (Stark \& Lucas, 1988; Stark \& Taylor, 1991). Families in the South with small landholdings can reduce risks by having members stay home to secure floor production of subsistence crops, while simultaneously maximizing security from variable alternatives with the remaining household labor through migration. However, it is important to note that the destination country in South-South migration often suffers domestic market failures as well, likely of different combinations and intensities. In addition, the NELM and remittance literature assumes a certain level of social stability in the home country. The families are often portrayed as residing in the same space, capable of making a decision for the collective good, able to fairly share their resources, and within stable communities. The relative stability of the social structure at the household and community level that migrants leave behind is highly variable, and thus influences the sense of obligation and altruism that is tied to remittances.

The risks that rural people in the South face are not only at the household and national levels; there are interconnected international and local factors that create "push" factors for migration. Much of the South, and nearly every country in Latin America and the Caribbean, has undergone structural adjustment (SA) intended to stabilize its economy through fiscal austerity, currency devaluation, privatization, and trade liberalization. ${ }^{4}$ This international development framework guides national policy, thereby changing local economic and social dynamics. Failures in the domestic economy resulting from financial reforms related to SA, such as the privatization of state-subsidized banks, and the elimination of subsidies in basic grain production in Costa Rica (Clark, 2001; Edelman, 1998, 1999; Fernández Arias, 2004) and Nicaragua (Enríquez, 2000; Spoor, 1994a, 1994b, 1995), have exacerbated the economic risks that families and communities face in the South. The lack of safety nets, such as limited options for loans and the challenges associated with paying them back, place rural families in the South at further risk, not just in agricultural production, but with regard to other factors in livelihood maintenance such as health and education. Although not much is known about remittances, there is speculation that families often use the funds to meet unexpected and recurring needs such as medicine and costs associated with education, namely purchasing school supplies, shoes, and uniforms (Ratha \& Shaw, 2007). It is questionable to what extent migrants are actually able to mitigate the risks their families face through migration. In considering South-South migration, where the relative wage differentials are much closer and where a larger portion of the wages earned are spent on food and housing, to what extent can South-South migrants have the economic capacity to assuage the consequences of domestic market failures in their home country?

The recent interest by scholars and policy makers in the general topic of migration and development based on remittances supports NELM theory by demonstrating the power of remittances and their potential for contributing to economic development in home communities (Orozco, 2002, 2003; Taylor, 1999). Mexican and El Salvadorian remittances from the United States illustrate how associations created by migrant communities in 
the United States have not only raised families' standards of living, but also have allowed migrants to pool their resources for collective economic development initiatives through hometown associations ${ }^{5}$ (Orozco, 2002; Orozco \& Dialogue, 2000). Migrant altruism and/or migrant obligations back home expressed through remittances make the perfect loop back to their home communities in the migration scenario where the burden of development is slowly being shifted from the state and international institutions to the individual migrants.

The presence and the absence of altruism are related to the work lives of migrants, and their ability to connect back to their families over time. Such an ideal feedback loop to the home country would imply that the intentions and the realities of migration are tightly linked. In the South-South migration case, where people come from places that are war torn and/or environmentally unstable, and have families who were displaced multiple times, the circular and transnational aspects of migration are more problematic. Migrants often do not have the option to return, not just for fear or political persecution, as framed within forced migration and refugee studies, but rather because the social and economic conditions do not allow for return. Families displaced multiple times may lose each other over time, leaving no home to go back to. In the transnationalism literature, the economic, political, and social connections that migrants have with their families and communities are also biased towards SouthNorth migrations. Social remittances are the cultural diffusion that occurs when people in disparate places are connected through information, visits, and money, through the process of international migration (Levitt, 1998). More broadly, transnationalism literature reveals how migrants are involved in the lives of the people back home and how the people back home have adopted the ideas and behaviors of places where they have never been (Levitt, 1998; 2001).

This paper examines the intentions and realities of South-South migration, migrants, and their families back home, to demonstrate the lack of connection, communication, and remittances between migrants and their families. This study illuminates the other side of migration: the side that is not connected, that does not come from stable families or communities, and that has not and cannot contribute to transnationalism or economic development. These are the "unsuccessful" migrants who are often forgotten or resented, they are rarely written or spoken about. At the broadest level, my findings problematize the relationship between remittances and development by moving away from the macroeconomic indicators and examining the lives of migrants and their families in the Southern context.

\section{Character of Nicaraguan migration into Costa Rica}

Over the past thirty years, Costa Rica has become home to an increasing number of Nicaraguans. In 1984, at the height of Nicaragua's civil war, less than 90,000 foreigners were living in Costa Rica and less than 46,000 of them were Nicaraguan (Castro Valverde, 2002 , p.5). Sixteen years later, the Nicaraguan population had grown nearly five-fold, from less than 46,000 to more than 226,000 , while the population of all other foreigners had not even doubled in size (from 43,000 to 70,000) (Castro Valverde, 2002, p.5). Nicaraguans now comprise $76 \%$ of the immigrant population in Costa Rica, not including the thousands of undocumented Nicaraguans who are both permanent and temporary residents in the country. The 2000 Census data and household surveys focus on many characteristics of 
documented Nicaraguans in Costa Rica and demonstrate that the Nicaraguan population in Costa Rica increased dramatically during the 1990s. Since the majority of documented Nicaraguans who participated in the 2000 census entered Costa Rica during the late 1990s, Costa Rican scholars and policy-makers largely claim that their motives for migration are driven by economic reasons rather than political ones (Borge, 2004; Morales \& Castro, 1999).

There are also nearly 300,000 Nicaraguan migrants living in the United States (U.S. Census Bureau, 2005). Many Nicaraguans fled their home country during the decade-long civil war during the 1980s, and were provided asylum in the United States. Both groups of migrants contribute to the $\$ 610$ million dollars (2001 estimates) remittances sent to Nicaragua (Jennings \& Clarke, 2005, p.685). Although $\$ 610$ million is a small amount compared to the estimated $\$ 10$ billion sent to Mexico (Sana \& Massey, 2005, p.517), remittances sent to Nicaragua represent 24\% of its GNP (Jennings \& Clarke, 2005, p.685), making Nicaragua the second largest remittance-receiving country in Latin America, as measured in its GNP, foreign direct investment, and official development assistance (Brown, 2006). ${ }^{6}$ In addition, it is estimated that large sums of informal transfers are made into Nicaragua and that SouthSouth remittances are significant in quantity (Agunias, 2006). Chaves Ramírez's remittance study found that $61 \%$ of Nicaraguan migrants send an average of $\$ 74.59$ dollars home every month (Chaves Ramírez \& Rojas Leiva, 2003, p.35) and 66\% of the remittance recipients use the money for food, clothing, and health related expenses (Chaves Ramírez \& Rojas Leiva, 2003 , p.38). A monthly remittance of $\$ 75$ per month contributes to $\$ 900$ of a family's yearly income where the average per capita income in Nicaragua is only $\$ 990$ (World Bank, 2007).

The findings from this study challenge the findings and assertions made about the significance of remittances on poverty alleviation and development in Nicaragua. Despite the impressive numbers, the hundreds of thousands of Nicaraguan migrants who do not and cannot send remittances, and their families who wait for their help, reveal the costs of migration. This paper first examines the disparities in responses and perceptions on both sides of the border. Then, it reveals the barriers to socially and economically connecting rural locales in the global South. Finally, the paper demonstrates how these barriers change the lived experiences of migrants and their families back home, illuminating the shortcomings of the migration, remittance, and development literature.

\section{Responses and Contradictions}

Although it is logical to believe that migrants exaggerate the amount of remittances sent and the number of phone calls made, and that their families underplay the amount of support and contact received, the reactions from the families superseded my most extreme expectations. Obligation and altruism were far from what I found during the family visits. The third family I visited in Nicaragua was Noel's. I met Noel early on in my fieldwork and visited him regularly when I made my rounds to conduct interviews in a small neighborhood on the outskirts of Pital, Costa Rica. He always offered me the only chair in the house, while he sat on the floor. He lived in a rented empty house with three other undocumented Nicaraguan men that remained void of furniture over the years that I knew him. They all worked together on a nearby pineapple farm with a contractor and hoped to return home soon. He gave me vague directions that he swore would get me to his mother's house and he 
claimed that he has maintained regular contact with his family and kids over years through phone calls and remittances.

I arrived in the large, dusty town of San Isidro in northern Nicaragua. I followed Noel's directions and got off the bus at a tire repair shack and I walked up the street past a small store and looked for a house on a corner as he had described it. It was the middle of the day and there were no people on the street or open doors in sight so I went back to the store to ask if they knew where the García family lived. The store owners, perplexed, referred me to a home a block away. I knocked on the door and asked the portly light-skinned middle-aged woman, "Does Lourdes live here?" There was a pause and a perplexed look, so I continued, "My name is Sang Lee a researcher from the United States. I am a friend of her son, Noel, who lives in Costa Rica, and I would like to speak with his mother." She answered abruptly, "What is wrong? Did something happen?" I quickly realized that I needed to change my approach with families of migrants. It became apparent how peculiar it was for a strange foreigner to come to their door claiming to know one of the family members. I told her that I was doing research and explained my motivations for wanting to speak to Lourdes. She commented that she had not heard anything from Noel in over seven months. She explained that he used to send money to her house and she would send it up to her aunt in San Andrés. She invited me in, offered me something to drink, and informed me that she was his cousin and his mother lived in the community of San Andrés. She explained that it was too late to begin a trip to San Andrés and recommended that I come another day when I can start the trip before six in the morning when it was cooler. There is no public transportation up to San Andrés, and it would be a few hours walk up a dirt road. She assured me that she would send her son with me to find Noel's mother.

Noel's mother's house was one of the first homes we came to on the main road. She lived in a small wooden shack, and she greeted me at the door. She was an elderly woman with long gray hair, deep wrinkles in her face, and rough hands. Laura already had sent her the message that I would be coming to bring news of her eldest son. She held my arm and immediately broke out into prayer to thank the Lord for bringing me to let her know that her son was okay. There were five young children in uniforms staring and whispering as Lourdes and I spoke. Noel's mother called a young girl over, Noel's daughter, and explained that she had been raising her since Noel left for Costa Rica. She told me how hard it was to send her to school:

There is no money...it is difficult here and I have had to take up the clay again [she held up a clay pot ${ }^{7}$ with tears in her eyes] and you can tell him when you go back that this is what I have come to, since my husband passed away I have just been hanging on...she misses her father, she tells me all the time that when she sees him again, she is going to run up to him and hug him and ask him to never go away again...We have been waiting for him to call, I have not heard from him in over seven months! I thought he was dead or in jail! (March 7, 2006).

Lourdes cried. At this moment I realized the difficult position I had put myself in to understand home country conditions. I could not bring myself to tell Lourdes that Noel had told me only two months ago that he sends money back home every two months. The inconsistency between 
Noel's statements and his mother's statements about their connection, my expectations of what these family visits were going to be, and the interview with Lourdes were my first glimpses of the emotional costs of migration. The coming months of the research proved that the situation with Noel and his family was the norm rather than the exception. I questioned the reliability of remittance sending mechanisms that migrants have access to in Costa Rica and where families can receive them in Nicaragua. Do they send the money and it does not get there? However, only a few families mentioned lost remittances through both formal and informal pathways. Follow-up interviews with migrant workers who claimed to have sent remittances, and their families' statements to the contrary, confirmed that the migrants exaggerated their remittance sending. Only after being confronted with the realities posed by their families, they explained the difficulty of saving money in Costa Rica. Migrants leave for work, but all of them leave expecting to return to Nicaragua regardless of their situation back home. Many migrant's intentions were hampered both by their inability to save and/or remit and by their inability to return.

The disconnect that migrants have with their families was veiled by the migrants' ambivalent responses during the interviews in Costa Rica. For example, like many of the other migrants in Pital, Cristino's answer concerning his communication back home was, "Sure, I call home, when I can....I would say about once a month" (Cristino, Nov. 7. 2005). While some honestly stated the difficulty of phone communication, many stretched the truth to me, and possibly even to themselves, about their links home to their families and communities. For example, Cristino's response does not mirror his crying mother's response. As Cristino's mother Lucia states:

I did not have luck with my children, I worked so hard to support them as a mother and I feel like I do not get anything in return...I do not ask anything of them, what I have is what I have from working and not from them (Apr. 19, 2006).

Lucia's sadness and frustration is related to the lack of both money and contact from her son. Like Lucia, many families feel abandoned by the migrants rather than supported, and many stated their inability to change this condition. Migrants' lives have changed through physical movement, and the lives of those who remain have changed as well. Perhaps families of migrants will tend to state that their situation is direr and the remittances and communication less frequent, thus possibly skewing the data toward the other side of the spectrum. I suspect that the reality ranges somewhere in between the two poles: the family situations are not as dire, but the remittances are not as frequent as the migrants state. In either case, they are distant from the migration and development paradigm. What was glaringly apparent during the interviews, and largely absent from the migration and development literature, is the prevalence of family dysfunction. That is, most families were not intact as a coherent nuclear family with a home village and a sense of belonging attached to a community. Many families have been and are displaced and poverty has strained the ties between family members.

The disparity between realities and intentions was further supported in the ethnosurveys conducted in eight communities in northern and southern Nicaragua. The ethnosurveys demonstrated similar findings about limited family contact and extremely limited 
remittances. Of the 121 ethnosurveys conducted, excluding the 33 visits with families of migrants from Pital, only 37 families claimed that they received remittances from their family members; the other 84 families said that they did not receive any. Billions of dollars are flowing into the South each year, presumably from the global North. However, this study found that in Nicaragua's countryside and within the context of South-South, rural-rural migration, the average amount of money sent to the families of migrants in Matagalpa was less than $\$ 40$ per month. Of the $43 \%$ of families receiving remittances in Nueva Guinea, the average remittance was only $\$ 18.11$ per month (see table 1 ), far from the findings from Chaves Ramírez's study of $\$ 75$ per month. Even in the second poorest country in the western hemisphere, $\$ 13$ per month can only function as a small gift. ${ }^{8}$ As such, the remittances did not function to sustain the migrants' families back in Nicaragua. Rather, they were sent as small gifts during the holidays; $\$ 20-40$ two times per year, thereby serving a social function, rather than an economic one.

The disparity in Chaves Ramírez's findings and the results of this study may be attributed to this study's focus on rural-to-rural migration, and the fact that higher portions of rural migrants are undocumented migrants. Thus, they earn lower wages and have less job stability. Although most of the respondents in the Chaves Ramírez's study were longterm migrants, in the case of agricultural laborers there might be a higher prevalence of temporary workers and circular migrants. The circular nature of their migration patterns would likely have migrants bring their money home rather than send it. In addition, although the data from this study does not support this claim, there might be a higher likelihood of the undocumented rural migrants sending remittances through informal means (i.e. with a friend or through encomienda systems). Even after considering alternative possibilities, the amount of remittances flowing from rural Costa Rica to rural Nicaragua is minimal.

Table 1. Family Remittances by Region

\begin{tabular}{c|ccccc}
\hline Region & $\mathrm{N}$ & $\begin{array}{c}\text { Receive } \\
\text { Remittances }\end{array}$ & No Remittances & $\begin{array}{c}\text { Percentage receiving } \\
\text { remittances }\end{array}$ & $\begin{array}{c}\text { Remittances received in U.S. } \\
\text { dollars per family per month }\end{array}$ \\
\hline Matagalpa & 40 & 27 & 13 & $67.5 \%$ & $\$ 39.49$ \\
Nueva Guinea & 81 & 35 & 46 & $43.2 \%$ & $\$ 18.11$ \\
\hline Total & $\mathbf{1 2 1}$ & $\mathbf{6 2}$ & $\mathbf{5 9}$ & & \\
\hline
\end{tabular}

Source: From the author's surveys and interviews.

\section{Southern Barriers}

Levitt defines social remittances as the transfer of intangible cultural practices from the destination to the home country. In her work, she uses the example of transference of teen clothing styles being remitted through migration (Levitt, 1998). The evidence of social remittances in Levitt's findings in the Dominican Republic are a far cry from the minimal cultural and personal information transferred between migrants in Costa Rica and their family members in Nicaragua. The families of migrants in Nicaragua expressed that they felt completely disconnected from their family members in Costa Rica. The cost of connection 
in which information can be shared prohibited most migrants and their families to maintain a connection. Even though the families resided only a few hundred kilometers away, the social and economic distance was so vast that families and their migrant kin were almost entirely disconnected from one another. There are infrastructural challenges to connecting two rural localities in the global South that do not exist between two urban localities where there is regular transportation, telephone lines and cellular phone towers, electricity, and remittance sending institutions (e.g. banks and Western Union). These challenges include both communication and financial barriers to connect migrants and their families, the first step in creating a transnational space or development through remittances.

\subsection{Emotional Distance}

The relative distance between families and migrants in the South are further complicated by the infrastructural challenges. Communication to and from rural areas in the South is difficult. Although Costa Rica's state-owned telecommunication system is one of the most extensive and least costly in Central America, it is still often difficult to connect to Nicaragua, and it is expensive. On Sundays, it is common to see a line of Nicaraguan migrants waiting to use a public telephone in both urban and rural Costa Rica. With their calling cards in hand, they wait patiently for their turn to communicate with their families back home. Ironically, it costs more than double to call Nicaragua from Costa Rica than it does to call the U.S. Nicaragua is one of the most expensive places to call from Costa Rica. ${ }^{9}$ A six minute calling card to Nicaragua is equivalent to one eight-hour minimum wage workday. The volume of calls on weekends to Nicaragua often makes it difficult for phone calls to get through, and migrants constantly expressed frustration about spending all of the money on phone cards without actually speaking to a person on the other side. On the other side of the border, many families living in rural areas do not have phone service in the community, resulting in long and costly trips to the city to receive phone calls. Often individuals who have private home phones will charge others receiving phone calls from Costa Rica. Phone calls are difficult and expensive for migrants and for their families, and many migrants choose not to call to save money to send to their families. The families assume that communication and remittance flow is the responsibility of the migrants, since the structural and economic challenges to communication are better understood by those who have crossed the border than those who remain at home.

The reasons people do not call are not only related to money and access, but also to an inability to meet implicit obligations to provide financial support. When I first met Pedro, for example, he stated that he planned to return to Nicaragua in February, around the same time that I was planning to go there to do the second part of my research. When February came, he explained that he spent a lot of money during the holidays on meat, some clothes and a few beers, and he currently did not have much work so he was going to delay his trip until Easter. I stayed with Pedro's older brother, his wife, and his sister-in-law for a week while conducting interviews and surveys in the town of Esquipulas, Nicaragua. His older brother pulled me aside and asked me, almost whispering, "Is it that he is not earning any money or that he is spending all of it? He still owes me money on the land that he bought from me and he has not sent money in over 9 months" (Abel, Mar. 13, 2006). Only a few 
months prior to my conversation with Abel, when I went to visit Pedro, he stated that he had recently sent his brother the last payment and that he was planning to move back as soon as he saved just a little bit more. "I am going back to Nicaragua and I am never coming back to this unthankful country! I am going back to farm and I am going to stay there and live off the land" (Pedro, May 14, 2006). Although Pedro was one of two migrants out of 110 interviewed who succeeded in purchasing land for agricultural production, nearly a year later he was still living ${ }^{10}$ and working in Pital. When asked about the lack of communication he stated frankly:

Call for what? They always ask to send money and if we do not have it, then we just feel bad. It is better not to call if I do not have any money waiting for them at the Western [referring to a remittance sending business]. They are going to wonder why we called if we are not sending money. That is the truth. They want us to send money and it is really hard with everything so expensive here (Jun. 1, 2006).

The guilt of not being able to support his family resulted in virtually no contact at all. My knowledge of his home situation and meeting his family incited a much more honest response from most of the migrants who I interviewed after my return. A packing plant worker who has not been able to send money home to her mother after her sister's death states jokingly: "they [people in Nicaragua] think that the donkeys here are defecating gold and all you have to do is get a shovel and put it in a sack"(Cecilia, Dec. 15, 2006). The gap between the perceived lives of migrants and the realities, compounded by the guilt of not being able to support their families, leaves migrants disconnected, frustrated, and isolated.

\subsection{Economic Distance}

Although they rarely have extra earnings to send home, there are also other barriers that keep migrants from sending remittances. First, the transactions costs are high for international money transfers. Agencies like Western Union charge 10\% of the total funds transferred. Although paying US\$5 to send $\$ 50$ does not seem like much, when $\$ 5$ is a day's earnings and can purchase nearly eight pounds of rice, many feel the transactions costs are too high to send money frequently. In addition, the person needs documentation in order to send or receive funds through a formal agency like Western Union. Not all migrants or migrants' families have identification cards or passports, and therefore, they cannot send or receive funds through formal channels. Even if they were to ask a person with documentation to send the money, the person on the other side must be advised and have documentation to receive the money. Banks facilitate the process by directly depositing funds into a bank account for a fee. But these formal means are just as difficult as any other means of remittance sending to remote areas. People in the economic and physical margins on both sides of the border have a hard time connecting to each other.

Little is known about remittance behavior in general, and some have speculated about its potential use and its possible role in economic development. Sriskandarajah states that remittance recipients use the monies primarily for basic needs such as food, clothing, and utilities (2005). Undeniably, the numbers are impressive; families and communities 
of migrants in Mexico received over 23 billion dollars in remittances in 2005, three billion dollars more than just five years ago (Banco de México, 2006, p.165). While states and agencies are looking for strategies to utilize the large flows of money for sustained economic development in the South, many of the findings currently demonstrate that households are merely sustained through the billions of dollars sent back home. The simple remittance and development argument needs to move beyond the myopic perception that capital flow is development and closely examine receiving communities and households to determine the types of changes occurring through remittances. This study of Nicaraguan migration into Costa Rica reveals more despair than development and suggests that the families of migrant workers tend not to experience improved economic conditions from sporadic remittances.

\section{Old Ties and New Beginnings}

Migrants live with the intention of returning to their home country, but years of delay and the loss of hope to save enough to resettle back in Nicaragua, result in the formation of new families and new beginnings in Costa Rica. Many migrants find themselves in a position where they cannot return, but they also cannot give up the idea of returning and settling permanently in Costa Rica. On the other side of the border, the migrants' families feel hopeless and in the dark about their migrant kin, but refuse to give up the idea that they will send money and eventually return to support them. The findings show that the migrants often find themselves in a state of liminality - they are not fully committed to their original families and communities in Nicaragua or to their new families formed in Costa Rica. Although few realistically have options for permanent return to the home country, even fewer migrants give up the romanticized idea of return as a successful migrant who can buy land and live off of it or start a successful business. This undying plan for return prevents their acceptance of their new life in which many people even have started new families. Their motivations for staying in Costa Rica are not necessarily to reap the benefits of higher wages or to lead a life that is economically, socially and politically secure. Relatively minor benefits such as slightly better infrastructure and the opportunity to eat meat more frequently were enough to keep migrants in Costa Rica, out of their homeland, and thus, away from their families. Building houses, buying land, educating their children, and/or funding agricultural production through remittances were simultaneously the goals of the naïve and recent migrants, and the distant dreams of the seasoned migrants who have worked relentlessly for years.

\subsection{Those Who Remain}

Many migrants choose to leave their small children in Nicaragua. The trip is dangerous and difficult, the conditions in Costa Rica are insecure, and the children's care is costly. The migrants' need for flexibility and mobility, and concerns about discrimination against Nicaraguans in Costa Rica, also deter many from bringing their children. As one migrant explained, "I did not want to bring them to suffer here, they do not need to be looked at poorly, they are only children!" (Juliana, Dec. 14, 2006). Hugo and his wife Ana brought their three young daughters to Costa Rica and, as Ana explained:

When we brought her here [referring to the youngest daughter], she was only a few months old. We crossed the border late at night and it took us a few days. We were all hungry and scared. When we crossed over there was the police and we had to run 
and hide in this bean field, we laid in the beans and there were so many mosquitoes, this poor little one got bit all over her arms and legs...this little one suffered a lot. She is not the same, she is smaller than the others (Ana, Dec. 23, 2005).

Similar stories of troubled border crossings travel back to Nicaragua, and potential or future migrants decide to leave their children home in hopes to earn money to support them and ultimately reunite the family. This leaves many struggling families in Nicaragua with the added responsibility of childcare. Strictly enforced child protection laws in Costa Rica also prevent migrants from bringing their children to Costa Rica. The very real threat of having their child taken away at the border or by the child protection agency leads many mothers and fathers to leave their children behind.

The lack of remittances places extra strain on those left with additional children to care for in Nicaragua. I asked one parent of a migrant if her overall situation has improved since six of her nine children left to Costa Rica. She stated:

Better? Noooooo...we are here, all by ourselves, in this little house and we do not have anything. He [referring to her husband] cannot work, he is too old and all of the kids are gone. We take care of these two [pointing to the two children about the ages of 8 and 10], we do not have money to buy shoes for them, let alone send them to school. This year we did not send them to school because I did not have money for shoes and I do not like to send them in sandals, so they will wait until next year...if they were here [their children], they would come by and give me a little something every day, even if it is a handful of beans, and they would raise these kids. What can we do here? We sit here and sell this [pointing to some textiles] and we pass the time doing this...it is not easy.... (Juana María, April 2, 2006).

This sentiment rang true throughout the Nicaraguan countryside. Frustrated parents of migrants, many taking care of their grandchildren, wondered what their children did with all of the money they were earning. Did they forget about their parents and their children? How could they not think about their family? The families of migrants often made accusations of poor migrant spending habits alongside comments expressing pity for their suffering in a strange country. The families felt both frustration and pity for their relatives across the border, who were facing difficult conditions without family or support.

On the other hand, families in the home country also commonly complained about family disintegration and unruly children in the absence of their birth parents. Levitt, in her study of Dominican migration to the U.S., found similar problems of family disintegration, even in the presence of remittances (Levitt, 2001). Similarly, families in Bolivia-where over a quarter of the population lives in other Latin American countries and in the global Northare dealing with large numbers of children abandoned by migrants (Almudevar, 2007).

The ethnosurvey revealed that migrants who left their children in Nicaragua tended to send remittances home more regularly. In fact, only families taking care of children of migrants received regular remittances. Other families supported the children-remittance connection when they explained that they received regular remittances while they took care of their 
grandchild, but the remittances stopped once the migrant took their children to Costa Rica. In such cases, remittances were only sent during emergencies and holidays. Only migrants who were living and working in a city (e.g. San José) and who had full time jobs sent both regular remittances and remittances sufficient to support a family.

The family visits and ethnosurvey interviews disclosed the emotional costs on the children and parents of migrants who are left behind. The families in Nicaragua do not know of migrants' failed plans for return, for visits or for the future, since communication is sparse. The hurt and frustration on one side and the guilt and shame on the other are unaccounted for in discussions of remittances and migration. The "successful" migrants steal the spotlight, thus, supporting the notion that development can occur through migration. Less successful migrants are overlooked by scholars, policy makers, and development practitioners who focus solely on the power of remittances and not on the detriment from the lack of them.

\subsection{New Families and New Marginalities}

Although migrants insist that they will return to Nicaragua, many do not. Racism, difficult working conditions, low wages, the high cost of living, and increased competition were among the many reasons that migrants stated that they did not want to stay in Costa Rica for the long-term. However, during the 18 months I conducted research, only a few migrants returned home to Nicaragua, although many more stated that they planned to go back during that timeframe.

When I first met Joaquín in late October, 2005, he told me that he planned to go back to Nicaragua within a year. He found the work in Costa Rica hard and unforgiving-the day we met was his first day off in over a year. He explained that he wanted to buy a small piece of land and go back to his hometown in northern Nicaragua so that he could be his own boss. He explained that he sent money home monthly to his mother and that he communicated often with his family in Nicaragua. Interestingly, when I asked his mother if Joaquín sent remittances, she stated: "None of my kids or my husband has ever sent me any money from Costa Rica, not even enough to buy a soda" (Juanita, Mar. 13, 2006). She went on to scold Joaquín, her oldest son, for abandoning his two children and his wife for another woman and her children in Costa Rica. That was when I realized that the photos of the children that Joaquín wanted to send to his mother were not actually his, but his current wife's children. David, like many migrants, had started another family in Costa Rica. While migrants are often conceptualized only as working bodies in foreign places, their personal lives play a role in migration dynamics. David disclosed that he was never happy with his wife in Nicaragua and saw migration as an easy way out. He laughed uneasily, but explained that he is happier with the woman he is currently living with, and migration has made his life better.

Joaquín returned to Nicaragua to visit his family and his new wife's family in the South in May 2006. I met with him after his return back to Pital from the visit in Nicaragua, and he mentioned that he was going to use his savings to buy a lot to build a house in Pital. His last visit confirmed that he was not going to return to Nicaragua permanently. From this visit, Joaquín's goals and intentions changed both for himself and for his new-found family. It left him with little hope for his home country's economic recovery, and he realized that he 
no longer had a place to call home there. He was from the North, but his wife was from the South in Nicaragua. While we sat on a small wooden bench in front of his rented shack, he complained about the high price of food in Nicaragua: "Here I get to eat meat twice a day, even though it is a small piece of meat. In Nicaragua, even the rich do not get to eat meat two times per day" (Joaquín, May 28, 2006). He told me a story about cooking fish soup on a Sunday during his visit. He explained that he spent over 300 córdobas buying fish and the root crops that needed to go in the soup for his family. He explained that earning 30-40 córdobas a day working as a farm hand in Nicaragua, he would never be able to afford fish soup. He stated that he does not want to live like that, he wanted to be able to satisfy small desires of eating something special every once in a while and he did not see it being a possibility as a landless peasant in Nicaragua. What seemed like minor benefits of living and working in a foreign country as a marginalized farm worker were significant enough to Joaquín and his family to remain in Costa Rica. Experiences such as this call for a recalibration of the costs and benefits of migration in the southern context.

Migrants in Costa Rica spoke of the difficulty of readjusting back to life in Nicaragua. Luxuries such as electricity, potable and running water, sewers, roads, and reliable transportation systems also contributed to people's extended stays in Costa Rica. Nicaraguan families saw such benefits as insignificant, and, at times, even expressed resentment towards those whose needs were now too sophisticated for the conditions at home. Nicaraguan families highlighted the comforts of living in one's home country near one's family without fear of deportation or racism. Mario, who first came to Costa Rica over 20 years ago, explains, "Now that I have been living in the pueblo (town), it is hard to go back to the fincas (farms), where it is dark. After all these years we get used to living here and it is not so easy going back" (Nov. 12, 2005). Similarly, a packing plant worker commented, "It is hard to go back now, we are accustomed to the life here and I have gone back and the water does not settle with me, I do not like drinking hot water..." (Juliana, Dec. 14, 2006). Individual migrants changed over time through the process of international migration, and this played a role in determining whether they returned. While Nicaraguan migrants are largely excluded from Costa Rican society at large, and intermarriage and even friendships are rare between Nicaraguans and Costa Ricans, the migrants have managed to assimilate, not culturally, but to the infrastructural conditions (electricity, potable water, flush toilets). Migrants are often emotionally torn and realize that the longer they stay, the harder it is to go back. At the same time, they are uneasy with the idea of staying permanently in Costa Rica, possibly because their options to settle permanently are limited. Undocumented migrants do not have access to stable jobs, deportation without due process is common, and there are many barriers for them to engage in the formal economy. Regardless of their legal status, all Nicaraguans in Costa Rica face xenophobia on a daily basis.

The incongruence between the relatively short physical distance and the long emotional and economic distance are symptoms of the structural and economic constraints of SouthSouth migration. The remittances sent by South-South migrants to their families in the case of Nicaraguans in rural Costa Rica suggest that they function not to spur economic development in Nicaragua's countryside nor to even reproduce and maintain the peasant household. Rather, these remittances function at best socially to marginally provide the migrant's presence and existence during holidays and family emergencies. Abandoned 
children, the elderly, and wives struggle to connect with their distant family member in Costa Rica, and remain searching for both reasons and explanations for their migration situation. This common story in the rural countryside is not the story that is commonly told about migration experience by scholars, policy makers, development specialists, and members of the community.

\section{Conclusions}

The disparities between migrants' original plans and the actual migration process demonstrate the "other side" of the migration story. Although other scholars have identified how development occurs through migration, and how migrants' home countries benefit greatly from their movement, these findings are not reflected in this study. Instead, this study demonstrates how the lives of people are physically and emotionally pushed and pulled between countries in the global South, and how the benefits of economic globalization largely fall on producers, and not necessarily on the landless migrants. Structural constraints, such as the logistical and economic barriers to remittance-sending, limit migrants' contact with their families. The despair that families and migrants feel through physical, communicative and economic separation is often overlooked in studies that examine migration and development. The transnational community developed by Nicaraguan migration into Costa Rica cannot be assumed for the rural context because the two communities are geographically close, yet separated by significant political, economic and infrastructural barriers that disconnect and disintegrate families involved in international migration. For many South-South Nicaraguan migrants, a transnational social and economic connection happens only in exceptional cases and with extreme effort from both sides of the border. Nicaraguan migration into Costa Rica demonstrates that distance is also context-dependent: even 200 kilometers is largely out of sight and reach of those in this study.

This paper highlights the constrained choices that migrants and their families have in the process of South-South migration, thus supporting the notion that the conditions of migrants and their families mirror those of forced rather than economic migrants. Examining the conditions at the household and individual level unveils the tensions and contractions on both sides of the border. The lack of communication and financial support, compounded by migrants' inability to return home due to financial constraints and perceived family obligations, essentially trap migrants in Costa Rica. The guilt, shame, and the infrastructural distance limits contact between migrants and their families, which leaves not only the families and children abandoned, but also the migrants. The literature on transnational communities and villages do not include the South-South, rural-rural migrants who do not have the social privilege of coming from a stable family and a stable village. In contrast, many of them are from war torn areas and their families have been repeatedly displaced and scattered throughout the country.

I attempt to examine the emotional costs of migration, and the minimal social function of remittances expose the challenges associated with developing social capital across structural distance and physically close localities. While studies of remittances overemphasize their impact on the migrant's country of origin, the migrants themselves are also under extreme amounts of pressure and suffer feelings of guilt. The latter often prevent a social connection back to their families because they cannot afford to have an economic one. Migrants and 
their families expressed feelings of frustration and abandonment despite their geographic proximity and their original intensions of migration. I was inadvertently an agent in creating a connection that otherwise would not have occurred, and the foundations of this paper arose out of this transnational connection that was only possible through my privilege. It is through this privileged lens that I was able to view the contradictions and despair of migration and the difference between the intensions and realities of migration.

\section{Notes}

1 All names have been changed to pseudonyms.

2 Ethnosurvey comprised of 69 questions using both survey and open ended questions on family histories, economic conditions, and migration dynamics.

3 None of the families had addresses. From the community, they usually provided a geographic and/or a personal reference point in the community so that I could find their families. Interestingly, few migrants actually believed that I would go to Nicaragua, let alone succeed in finding their families in remote villages. A few migrants did not provide me with enough information to find their family members. One family moved from the village, and other families lived more than five hours walk from the last stop on public transportation. I determined five hours to be the cut off because any place further away would be impossible to walk the round trip and conduct the interview in one day's worth of day light. I chose not to visit one family due to the prevalence of leishmaniasis in the region. One family declined to be interviewed. Housing and food was slightly problematic since none of the villages had places to stay or eat. In nearly all of the villages, I stayed on the floor of families of migrants or community leaders.

4 Some countries have not undergone structural adjustment, for example Cuba. Others have undergone SA early like Chile and Argentina, while others are late reformers such as Nicaragua. More specifically some sectors of the economy have undergone SA while others have not (c.f. Enríquez forthcoming).

5 Hometown associations are organizations formed by immigrants from the same town who have decided to pool their remittance money together to fund community development projects such as a community building, a basketball court, or an aqueduct.

6 El Salvador receives the most remittances relative to their GDP and foreign direct investment.

7 She considered producing clay pots was the absolute last resort, other than begging. She explained the shame of an elderly woman with sons who are of working age to produce clay pots. Clay pots are used to cook beans on the fire in Nicaragua. They have largely been replaced by metal pots, but some families in the countryside still use them and claim that beans taste better cooked in clay pots.

8 At the time of the study $\$ 13$ could purchase about $15 \mathrm{lbs}$ of rice.

9 The call centers in San José charge between 100-200 colones per minute (about 25-50 cents). In rural areas there are no call centers, and migrants rely on prepaid calling cards that range in value from 500-3000 colones (US\$1-6).

$10 \mathrm{He}$ and his three housemates lived in a small empty house near one of the large pineapple farms. Although they lived in the same house for over two years, they did not have any furniture, and we sat on rocks and cinderblocks. It was questionable whether they had beds to sleep on. Since all of them were planning to return to Nicaragua in the near future, they did not bother investing in any material goods in Costa Rica.

\section{References}

Agunias, D. (2006). Remittance Trends in Central America. Journal of Development Economics, 72, (2), 369-382. Retrieved on April 1, 2006 from www.migrationinformation. org/Feature/print.cfm?ID $=393$

Almudevar, L. (2007, October 13). Bolivia's Abandoned Children. BBC News. Retrieved on October 13, 2007 from http://news.bbc.co.uk/2/hi/programmes/from_our_own_ correspondent/7048691.stm 
Banco de México. (2006). Informe Anual 2006. Distrito Federal: Banco de México.

Borge, D. (2004). Migraciones de nicaragüenses hacia Costa Rica: análisis de dos redes sociales. San José: Universidad de Costa Rica.

Brown, S. S. (2006). Can Remittances Spur Development? A Critical Survey. International Studies Review, 8(1), 55-76.

Castro Valverde, C. (2002). Migración nicaragüense en Costa Rica: población, empleo y necesidades básicas insatisfechas. San José: Facultad Latinoamericana de Ciencias Sociales.

Chaves Ramírez, E., \& Rojas Leiva, G. (2003). Aspectos socioeconómicos de las remesas familiares en Costa Rica, 2003. San José: Banco Central de Costa Rica.

Clark, M. (2001). Gradual Economic Reform in Latin America: The Costa Rican Experience Albany: State University of New York Press.

Edelman, M. (1998). Transnational Peasant Politics in Central America. Latin American Research Review, 33(3), 49-86.

Edelman, M. (1999). Peasants Against Globalization: Rural Social Movements in Costa Rica. Stanford: Stanford University Press.

Enríquez, L. (2000). The Varying Impact of Structural Adjustment on Nicaragua's Small Farmers. European Review of Latin American and Caribbean Studies, 69, 47-68.

Fernández Arias, M. (2004). La agricultura costarricense ante la globalización, las nuevas reglas del comercio internacional y su impacto en el agro. San José: Editorial de la Universidad de Costa Rica.

Jennings, A., \& Clarke, M. (2005). The development impact of remittances to Nicaragua. Development in Practice, 15(5), 685-691.

Levitt, P. (1998). Social remittances: migration driven local-level forms of cultural diffusion. International Migration Review, 926-948.

Levitt, P. (2001). The Transnational Villagers. Berkeley: University of California.

Morales, A., \& Castro, C. (1999). Inmigración laboral nicaragüense en Costa Rica. San José: Facultad Latinoamericana de Ciencias Sociales.

Orozco, M. (2002). Globalization and Migration: The Impact of Family Remittances in Latin America. Latin American Politics and Society, 44(2), 41-66.

Orozco, M. (2003). Family remittances to Nicaragua: Opportunities to increase economic contributions of Nicaraguans living abroad. Washington, DC: United States Agency for International Development.

Orozco, M., \& Dialogue, I. A. (2000). Latino Hometown Associations as Agents of Development in Latin America. Washington: Inter-American Dialogue; Tomás Rivera Policy Institute.

Ratha, D. (2003). Workers' Remittances: An Important and Stable Source of External Development Finance. Global Development Finance, 2003, 157-175.

Ratha, D., \& Shaw, W. (2007). South-South Migration and Remittances. Washington, D.C.: World Bank Publications.

Sana, M., \& Massey, D. S. (2005). Household Composition, Family Migration, and Community Context: Migrant Remittances in Four Countries*. Social Science Quarterly, 86(2), 509528.

Spoor, M. (1994a). Neo-Liberalism and Institutional Reform in Post-1990 Nicaragua: The Impact on Grain Markets. Bulletin of Latin American Research, 13(2), 185-202.

Spoor, M. (1994b). Issues of State and Market: From Interventionism to Deregulation of Food 
Markets in Nicaragua. World Development, 22(4), 517-533.

Spoor, M. (1995). Liberalization of grain markets in Nicaragua. Food Policy, 20(2), 99-110.

Sriskandarajah, D. (2005). Migration and Development. World Economics, 6(2), 141.

Stark, O., \& Bloom, D. (1985). The New Economics of Labor Migration. The American Economic Review, 75(2).

Stark, O., \& Lucas, R. E. B. (1988). Migration, Remittances, and the Family. Economic Development and Cultural Change, 36(3), 465-481.

Stark, O., \& Taylor, J. E. (1991). Migration Incentives, Migration Types: The Role of Relative Deprivation. The Economic Journal, 101(408), 1163-1178.

Taylor, E. J. (1999). The New Economics of Labour Migration and the Role of Remittances in the Migration Process. International Migration, 37(1), 63-88.

U.S. Census Bureau. (2005). B03001. Hispanic or Latino Origin by Specific Origin - Universe: Total Population. In -. A. C. S.-Y. Estimates (Ed.). Washington DC: U.S. Census Bureau.

World Bank. (2007). Key Development and Data Statistics. Retrieved on May 5, 2009, from http://web.worldbank.org/WBSITE/EXTERNAL/DATASTATISTICS/0,,contentMDK :20535285 menuPK:1192694 pagePK:64133150 piPK:64133175 theSitePK:239419 i sCURL:Y isCURL:Y,00.html 